\author{
УДК 81'38 \\ DOI 10.35433/philology.1(89).2019.146-150
}

О. Б. Януш,

кандидат філологічних наук, доцент

(Київський національний торговельно-економічний університет) BERSERKER@ukr.net

ORCID: 0000-0001-6171-0178

\title{
СТРУКТУРНО-СТИЛІСТИЧНІ ОСОБЛИВОСТІ ЕВФЕМІЇ В АСПЕКТІ ФУНКЦІОНАЛЬНОГО РОЗВИТКУ МОВИ
}

У статті досліджено проблематичні засади зв'язків між структурними та функиіональними аспектами мови, що мають цілу низку характерних особливостей. Обтрунтовано стилістичну однорідність / неоднорідність різних ролей співрозмовників, їх співвідношення в соиіальній взаємодії, у мовному полі якої функціонують евфемізми, як інструмент вербального впливу на співрозмовника. Окреслено особливості зрушення денотативного значення евфемізмів та вплив такого процесу на маніпулятивний аспект дискурс .

Ключові слова: структурний і функціональний аспекти мови, роль співрозмовника, евфемізм, політичні евфемізми, дисфемізм, дискурс, маніпулятивний аспект.

Постановка проблеми. Лексико-фразеологічний склад і структура будь-якої мови істотно залежить від його функціонального розвитку. Деякі елементи мови виконують свою власну функцію, яка виявляє свою природу як особливий компонент структури. Функції мови не виходять за рамки ії структури і тому визначаються як мовна функція. У свою чергу, мова виконує не тільки лінгвістичну функцію як таку, оскільки іiі роль не може бути замкнута на собі. Вона входить як специфічний компонент в іншу систему - систему соціальних явищ, що займає своє особливе місце всередині неї. Тому мовні властивості характеризуються, перш за все, своєю соціальною природою.

Немає сумніву, що кожна людина у відповідному життєвому просторі та комунікативних ситуаціях повністю або у більшості випадків проявляє себе у рамках і в параметрах конкретної мовної підсистеми, певного функціонального стилю. Учасник комунікативного акту за будь-яких обставин виконує певну інтелектуальну та мовну роль, яка стилістично диференційована. Тому вивчення мовного аспекту рольової поведінки ораторів необхідно починати досліджувати 3 точки зору функціонального та стилістичного вивчення цього питання.

Аналіз основних досліджень і публікацій. Неодноразово лінгвісти, філософи й психологи зверталися за різних обставин до питань, що стосуються функціонування мови. Наприклад, деякі лінгвісти виділяють такі стилі, як офіційно-документальний або діловий, публіцистичний, науковий, бізнес-технічний, художній, розмовний та інші. На нашу думку, така класифікація за стилями може бути представлена більш детально.

До невирішених питань на сьогодні, за нашою думкою, необхідно відносити дослідження різних шарів мови, безпосередньо мовлення і комунікації у тісному зв'язку з лінгвопрагматичним аспектом їх вживання у різних функціональних стилях, жанрах тощо вивчаючи такі явища, як наприклад дискурс у різних сферах діяльності і спілкування. Останні роки характеризувалися значними успіхами у вивченні мовних явищ у широкому соціальному контексті. Проте, у соціолінгвістиці, що є дуже важливою галуззю сучасної лінгвістики, деякі проблеми недостатньо висвітлені.

Метою нашого дослідження є вивчення характерних ознак функціонування мови, що в певному сенсі $\epsilon$ притаманним використовуватись у різних сферах діяльності, у яких зазвичай використовуються слова i вирази, що підлягають певному стилю або жанру і поєднуються у ньому за ї комбінаторними властивостями, конотативним забарвленням, здатністю бути субституйованими іншими словами та виразами з метою найбільш конкретної і точної передачі думки мовця.

Виклад основного матеріалу. Припустимо, що соціальний фактор займає одну з найважливіших позицій під час побудови висловлювань. Зазначена ізоляція і контрольоване використання засобів мовного вираження диктуються соціальними відчуттями, які зумовлені характером відносин між співрозмовниками і саме тим, що вони взаємоспрямовані (наближені) один до одного завдяки, перш за все, певним спільним соціальним та інтелектуальним рисам, притаманним їм.

Зв'язки між структурно-функціональними аспектами мови мають низку відмінних ознак, які, на жаль, не завжди повністю враховуються фахівцями під час вивчення функціонування мови серед осіб або груп людей, пов'язаних одним видом активності.

3 функціонально-стилістичної точки зору роль кожного з учасників комунікативного акту стає важливою в аспекті тих структурно-стилістичних особливостей свого мовлення, які співрозмовники самі й впроваджують, а потім активно використовують. 
Для стильової однорідності / неоднорідності різних ролей, у яких роль як така не "нав'язує" самого ії значення, а взаємозв'язок мовлення з роллю партнера акту комунікації визначається в їх соціальній взаємодії. Стилістично більш-менш однорідними є соціальні ролі, у яких, ми вважаємо, варто виділяти такі характерні риси, як взаємозв'язок співрозмовників, наприклад: офіційна - нейтральна - дружня інтимна. Тому, реалізуючи ролі "голова" і "підлеглий", постає чимало спільних стилістичних особливостей, оскільки кожна 3 них проявляється у формальних відносинах між рольовими партнерами. Характерно, що при виконанні вільних ролей (наприклад, ролі друзів), вибір стилістичної доцільності теж не є вільним. Такий вибір орієнтований на певні стилістичні сфери, скажімо, стиль невимушеної розмови.

У свої дослідженнях ми намагаємося поєднати концепцію відомих психолінгвістів у тлумаченні понять норми та нормалізації мовних процесів. Не існує загальної семантико-функціональної норми, яка б слугувала стандартом для всіх випадків спілкування. Водночас існує система правил, диференційована щодо різних особливостей мовної ситуації та інших характеристик комунікацій.

Для мовленнєвої культури особливо важливими є індивідуальні та соціальні групові оцінки мовних процесів. Такі оцінки сигналізують про критерій доцільності, правильності, адекватності вибору тощо. Лексеми типу напад (пограбування, розбій) можна зустріти в різних стилях, але тільки в офіційному документальному стилі певної професії або лише кількох професійних груп вони використовуються досить регулярно і послідовно.

Вплив соціального фактора чітко простежується у змінах лексико-фразеологічного складу мови, що визначається, зокрема, чинниками пристойності / непристойності мовленнєвого акту. Для передачі інформації того чи іншого змісту, умовно прийнятного або ж ні, у мові вживаються спеціальні займенники; вони зберігаються в лексиці, поки не почнуть сприймаються як жорстокі чи непристойні форми висловлювання.

Кореляції моралі та мови вивчаються менше, ніж співвідношення типу "наука і мова", "технологія $\mathrm{i}$ мова", "література і мова" тощо. Водночас, існування значного шару евфемістично-дисфемістичної лексики і фразеології сучасних мов зобов'язане впливу моральних, етичних та естетичних чинників на вибір стилю спілкування. У зв'язку з цим і виникає проблема вивчення евфемізмів та суміжних 3 ними лінгвальних явищ. Створення фундаментальних досліджень сучасної лексикології неможливе без попереднього поглибленого вивчення окремих груп і шарів лексичного складу мови, що пояснює актуальність і значущість досліджень, здійснених у цьому напрямку.

Зазначимо, процеси появи лексико-семантичного евфемізмів відбуваються регулярно у будь-якій мові протягом певного періоду історії. Як наслідок, в тлумачних словниках та інших лексикографічних виданнях немає чітко сформульованих принципів фіксації евфемізмів. Водночас, евфемізм, як вважають вітчизняні та зарубіжні дослідники, стає кількісно значним шаром лексики і фразеології різних мов. Тому цей словниковий шар, який розкриває як комунікативні, так і естетичні функції мови у якісному аспекті, заслуговує на особливу увагу. Загальновідомо, що зазначений лексичний і фразеологічний склади мови $\epsilon$ найбільш динамічними підсистемами або їі структурними компонентами, які відображають найрізноманітніші уявлення суспільного життя, менталітет носіїв мови і психологію людей. Для сучасного спілкування важливим є сприйняття будь-яких реалій життя, звичних виразів думки і почуттів, емоцій як в прямому (простому, звичайному), так і у відвертому вигляді словоформ. Адже у цілій низці випадків у певних ситуаціях конкретні суб'єкти, явища, процеси певних сфер суспільного життя постійно набувають непрямих, вторинних назв з точки зору конкретних життєвих i ситуаційних обставин. У цих назвах існує постійна комунікативна потреба.

Евфемізми розглядаються як явища, що призводять до значних змін у семантичній структурі висловлювання. У зв'язку з цим постає питання про те, чи можна класифікувати метафору, метонімію та інші тропи як евфемізми, якщо останні виникають у мовленні в результаті певних заміщень у семантичній структурі слів. Ці зміни трактуються дослідниками по-різному. Наприклад, ми маємо на увазі можливість поступової позитивізації або ж, навпаки, негативізації семантики евфемізмів, аж до їх перетворення у дисфемізми. За нашими спостереженнями, в деяких випадках такий процес відбувається регулярно.

Суперечливі моменти трапляються і в сучасних дослідженнях з цієї проблеми, зокрема, - це питання політичних евфемізмів, іронічних псевдоевфемізмів, криптологічних висловлювань, дисфемізмів, какофемізмів тощо.

Причиною суперечливих або взаємоспрямованих семантичних зрушень та переміщень смислових навантажень слів і навіть семантично структурованих текстів є мовно-прагматичні і мовно-соціальні явища. У сучасному мовознавстві їх визначення визначаються дискусійним підходом до цього явища в контексті вивчення аспектів комунікативного акту, зокрема, і теорії комунікативних актів взагалі. Спостерігаючи за мовними одиницями з різних ракурсів та альтернативних точок зору, можна визначити роль різних мовних та екстралінгвістичних явищ, які відіграють важливу роль у пізнанні та подальшому вивченні певного лінгвального феномену. Очевидно, що ми маємо на увазі феномен дискурсу. 
На підставі вивчення та аналізу різних наукових та лексикографічних матеріалів ми дійшли висновку, що різнобічні підходи до інтерпретації дискурсу не охоплюють усіх аспектів його природи, не повністю відображають особливості його утворення та функціонування в комунікативному просторі. Визначаючи пріоритет того чи іншого аспекту дискурсу, дослідники надають цьому терміну різного смислового змісту.

Відомо, що дискурс у загальному сенсі - це мова, мовлення, процес мовленнєвої діяльності. У спеціальному, соціально-гуманітарному сенсі дискурс є соціально визначеною організацією мовної системи, що характеризується певними принципами, які класифікуються особливим чином i відтворюються у той чи інший період часу.

Досить регулярно дискурс розглядається серед основних понять і термінів політичної лінгвістики в контексті політичної комунікації, тобто в процесі комунікації між учасниками політичної діяльності. Найбільш важливим для політичного мовознавства терміну дискурс поки що немає єдиного визначення. Термін дискурс може бути використаний для позначення мовленнєвої діяльності, тексту, контексту та вираження комунікативної ситуації в їх взаємозв'язку. Отже, якщо розглядати дискурс як складну єдність лінгвістичних форм, сенс якого полягає у "комунікативній події", то такий термін відповідає низці визначень, порушуючи як суто інтуїтивні, так і лінгвістичні підходи щодо його визначення, не обмежуючись фреймами специфічного мовного висловлювання, тобто у межах самого тексту або діалогу, вербального і невербального.

Таким чином, під поняттям дискурсу ми маємо на увазі багатовимірне явище, що визначається соціальними, історичними, прагматичними, психологічними, етнокультурними факторами, які притаманні, перш за все, певним лінгвістичним структурам (синтаксичний зв'язок, лексичне значення, семантичні зрушення і т. ін.) i, звичайно ж екстралінгвістичним структурам (думки, прагматичні цілі, інструкції, жести, кінетика, які необхідні для адекватного розуміння висловлювання). Дискурс поєднує в собі текст, процеси його генерації, що забезпечує додатковий зміст, закладений адресатом для досягнення прагматичних цілей, і процеси його сприйняття людською свідомістю, в яких відображується підтвердження обставин і умов спілкування. Крім того, процеси генерування та сприйняття дискурсу визначаються комунікативною ситуацією, яка є спільною для обох частин спілкування.

Термін дискурс також має як лінгвістичну, так i соціальну природу. Це предмет вивчення лінгвістичної культури, соціолінгвістики, психолінгвістики, політичної лінгвістики. Існують дискурси різного характеру та походження, наприклад, мітинги, парламентські вибори, дискурс виборчої кампанії та інші. В останні роки було зафіксовано багатоохоплюючий дискурс на теледебатах і ток-шоу. Одним 3 різновидів цього виду дискурсу є мас-медіа дискурс, усний чи письмовий, який має прагматичні, соціокультурні, психологічні та інші фактори, що виражаються через засоби масової комунікації і відображають механізм свідомості комунікаторів. Мовні акти, такі як табу, вимоги, запити, заперечення, аргументи, твердження, вислови, розбіжності, спростування та багато інших є ознакою маніпулятивного дискурсу.

Оскільки важливою частиною дискурсу є його комунікативний модус, який реалізує семантичний i прагматичний зміст, то стиль дискурсу може бути змінений спікером, який залежить від фактора адресата і ситуації спілкування. Варіативність дискурсу, відтвореного спікером через посередництво фактора адресата може функціонувати в різних стилях, відповідно до прагматичних намірів оратора. Таким чином, для звернення до високопоставлених спікерів, швидше за все, вибиратиметься офіційний бізнес-стиль, а привертаючи увагу так званої середньостатистичної аудиторії, стиль буде ближче до звичайного, повсякденний. Таким чином, функціональний стиль $є$ формальною структурою, яка діє у певній сфері життя і характеризується певним набором мовних і позамовних факторів. Зміни в дискурсі можливі з метою досягнення прагматичних цілей, залежно від фактора адресата.

Беручи до уваги вищезазначене і водночас спостерігаючи за структурою евфемізмів у спеціальній термінології, зокрема політичній, стверджуємо, що політичні евфемізми формуються на основі різних характеристик їх денотативного значення як концептуального смислового центру, смислової складової, що абстрагується від різних конотацій. Вибір методів і характеристик залежить від прагматичної мети. Неоднозначність, як різниця в значенні слів мови політики, пояснює існування різних підходів до відтворення думки. У разі евфемізації окремих мовних одиниць або дискурсу в цілому можна емоційно оцінити позитивні або негативні позначення висловлювання або ж тексту.

Соціально-політична лексика стабілізувалася поступово; на сьогоднішній день вона стає все більш систематим мовним шаром. Формування соціально-політичних, правових, військових термінів не $\epsilon$ випадковим за своїм характером, а переважно регулюється і моделюється. Політичні словники фіксують найрізноманітніші смислові зрушення, перетворення, що відбувалися в усній і письмовій мові, включаючи евфемію.

Питання політичного евфемізму залишається спірним. Цьому аспекту доцільно було б приділити більш уваги і більш ретельно дослідити зазначене явище. 
До політичних евфемізмів лінгвісти відносять такі одиниці, як лексеми та лінгвістичні висловлювання, які відображають суспільні погляди спікерів-політиків та політичних коментаторів, їх наміри, словесні стратегії тощо. Вони включають соціальний детермінізм їх формування в мові, бінарні протилежні паралельні імена, а також прагнення "завуалювати" концептуальну складову в семантиці слова. У певному сенсі ми можемо навіть припустити, що термін "політичні евфемізми" охоплює назви понять, створених для спотворення фактів, зокрема, соціальних і політичних.

Безумовно, аналізуючи евфемізми, необхідно пам'ятати, що табу самі по собі не підлягають субституції; вони спрямовуються на свої номінації, замінам підлягають лише значення, що позначають певні імена та номінації. Евфемізм у своєму денотативному значенні повинен бути таким самим, як i значення табу, що замінюється. Отже, теза про те, що політичні евфемізми є лише викривленням понять може бути виправдана таким способом субституції. Проте, навряд чи можна погодитися з твердженням, що політичні евфемізми не збігаються з іхніми денотативними значеннями з іменами-табу або з будьякими іншими назвами, які вимагають підміни або заміни. Водночас, не має сумніву в тому, що політичні евфемізми частіше, ніж інші типи евфемізмів, відповідають криптології та іншим суміжним формам мовного переосмислення у соціально-політичній сфері спілкування.

Складність розмежування політичної мови та політичного евфемізму полягає в тому, що паралельні імена, які знаходяться в ролі, скажімо, евфемізмів у політичній лексиці, семантично позитивні у своій внутрішній формі або ж у нових варіантах, на відміну від описових політичних виразів, які можуть мати будь-які емоційно-експресивні забарвлення. У таких випадках екстралінгвістичний фактор соціальної значущості та негативності або позитивності похідного концепту на основі загальноприйнятих соціальних оцінок відмежовує евфемізм від нейтрального відрізку акту комунікації як такого.

Різна прагматична орієнтація двох типів мови відповідно викликає різні перетворення в семантиці слів. Що стосується політичної лексики, то заміна всередині цього шару можлива як 3 точки зору перекручування оригінальної концепції, так і по відношенню до їі похідного відтворення, тобто можливі зміни змістового плану і плану вираження.

3 упевненістю можемо припустити, що евфемія - це дискурсивно-когнітивне явище, вид непрямого спілкування, спрямований на заміну уявлення адресата про світ (картину світу) 3 метою досягнення конкретного ефекту. Евфемія також розглядається в порівнянні з переконливими практиками мовлення. Словесний переконливий, який може бути маніпулятивним, вплив на слухача - це мова, яка передбачає зміну ставлення адресата до предмета мови, i, як наслідок, дії адресата в інтересах адресанта.

Лінгвістичне значення евфемії співвідноситься з естетикою античності: вона є власністю, перш за все, душі, протистоїть поганим вчинкам, богохульства і ненормативної лексики, результатом самостійного самовдосконалення і споглядання.

На сьогоднішній день у деяких промовах використовується велика кількість евфемізмів. 3 іншого боку, маніпулятивний тип ідеології, тісно пов'язаний 3 мовою тоталітарних суспільств, породив культурні евфемізми, що що подекуди залучаються до змісту маніпулятивного і обсесивного дискурсу і навіть іноді до так званого "мовного насильства".

Висновки та перспективи подальших досліджень. Підсумовуючи вищезазначене, ми можемо 3 упевненістю стверджувати, що функція евфемізмів залежить від функціональних стилів, у яких вони використовуються. Евфемізми приховують негативні реалії, включаючи сферу міжнародних відносин, політичну, соціальну та інші сфери життя. Вони використовуються у формах дипломатичної ввічливості, висловлюючи повагу на основі взаємності або навпаки, можуть перерости у пристрій маніпулятивного характеру.

3 упевненістю можна стверджувати, що в основі більшості лінгвістичних досліджень полягає підхід, що визначає вивчення мови як інструменту мовної та мовленнєвої (дискурсної) діяльності іiі носіїв, а також стилів і жанрів, в яких вони функціонують. Ми розглянули основні причини та природу походження евфемізмів, а також способи їх функціонування, зокрема, у політичній сфері діяльності; їх подальше перетворення в слова 3 нейтральним, загальним або описовим значенням а також їх перехід у дисфемізми і навіть зникнення і вилучення з вокабуляру.

\section{СПИСОК ВИКОРИСТАНИХ ДЖЕРЕЛ І ЛІТЕРАТУРИ}

1. Большой англо-русский словарь : в 2-х томах / Авт. Апресян Ю. Д., Гальперин И. Р. и др. - 4-е изд.. - М. : Рус. яз., 1987.

2. Blackledge A. Discourse and Power in a Multilingual World/ A. Blackledge. - Philadelphia, USA : John Benjamins B.V., 2009. - 253 p.

3. Fairclough N. Critical Discourse Analysis. In T.A. van Dijk (ed.), Discourse Studies. A Multidisciplinary Introduction, Vol. 2. Discourse as Social Interaction. - London : Sage. - Pp. 258-284.

4. Кацев А. М. Эвфемия в современном английском языке. Опыт социолингвистического описания : дисс.... на соискание уч. степени канд..филол. наук / Кацев Анри Матвеевич. - Л. : ЛГПИ имени А. И. Герцена, 1977. 
5. Селіванова О. О. Сучасна лінгвістика: напрями та проблеми : [підручник] / О. О. Селіванова. - Полтава : "Довкілля-К". - 2008. - 712 с.

6. Teun A.van Dijk Critical Discourse Analysis // The Handbook of Discourse Analysis // Edited by D. Schiffrin, D. Tannen, H. E. Hamilton. Blackwell Publishing Ltd. - Oxford, UK. - 2008. - Pp. 352-371.

7. Януш О. Б. Евфемія та суміжні явища в українській і російській мовах : дис.... канд.. філол. наук : 10.02 .01 ; 10.02.02 / Януш Олег Богданович. - К. : НПУ імені М. П. Драгоманова, -1997. - 189 с. (Першотвір).

\section{REFERENCES (TRANSLATED \& TRANSLITERATED)}

1. Bolshoi anglo-russkii slovar' [Large English-Russian Dictionary] : v 2-h tomakh / Avt. Apresian Y. D., Galperin I. R. i dr. - 4-e izd - M. : Rus. yaz., 1987.

2. Blackledge A. Discourse and Power in a Multilingual World/ A. Blackledge. - Philadelphia, USA : John Benjamins B.V., 2009. - 253 p.

3. Fairclough N. Critical Discourse Analysis / In T.A. van Dijk (ed.), Discourse Studies. A Multidisciplinary Introduction. - Vol. 2. Discourse as Social Interaction. - London : Sage. - Pp. 258-284.

4. Katsev A. M. Evfemia v sovremennom angliiskom yazyke. Opyt sotsiolingvisticheskogo opisaniia : diss.... na soiskaniie uch. stepeni kand. filol. nauk / Katsev Anri Matveievich. - L. : LGPI imeni A. I. Gertsena, 1977.

5. Selivanova O. Suchasna lingvistyka : napriamy ta problemy [Modern Linguistics: Directions and Problems]: [pidruchnyk] / Selivanova Olena. - Poltava : "Dovkillia-K". - 2008. - 712 p.

6. Teun A.van Dijk. Critical Discourse Analysis // The Handbook of Discourse Analysis.// Edited by D. Schiffrin, D. Tannen, H. E. Hamilton. Blackwell Publishing Ltd. - Oxford, UK. - 2008. - Pp. 352-371.

7. Yanush O. B. Evfemia ta sumizhni yavyscha v ukrainskii i rosiiskii movakh: dis.... kand. filol. nauk: 10.02.01 ; 10.02.02 / Yanush Oleh Borysovych. - K. : NPU imeni M. P. Dragomanova, - 1997. - 189 p. (Manuscript).

\section{Януш О. Б. Структурно-стилистические особенности эвфемии в аспекте функционального} развития языка.

В статье исследованы проблемы основы связей между структурными и функциональныли аспектами языка, которые обладают целылм рядом характерных особенностей. Обоснованно стилистическую

однородность / неоднородность различных ролей собеседников, их отночения в социальном взаимодействии, в языковом поле которых функичонируют эвфемизмы, как инструмент вербального воздействия на собеседника. Определены особенности сдвигов денотативного значения эвфемизмов и влияние такого процесса на манипулятивный аспект дискурса.

Ключевые слова: структурный и функциональный аспекты языка, роль собеседника, эвфемизм, политические эвфемизмы, дисфемизм, дискурс, манипулятивный аспект.

\section{Yanush O. B. Structural-Stylistic Features of Euphemism in the Aspect of Functional Development of Language.}

The article deals with the problematic foundations of the relations between the structural and functional aspects of the language, having a number of characteristic features. Stylistic homogeneity / heterogeneity of various roles of interlocutors; their correlation in social communication within linguistic field, where euphemisms function as a tool of verbal influence on the interlocutor. The features of denotative meaning of euphemisms and the influence on the manipulative aspect of discourse in the context of the socio-political functioning of the latter are outlined.

The term discourse is also considered both as linguistic and social phenomenon. This is a subject of studying linguistic culture, sociolinguistics, psycholinguistics, political linguistics. There are discourses of a different nature and origin, for example, parliamentary elections, discourse of the election campaign, and others.

Discourse is considered among the basic concepts and terms of political linguistics in the context of political communication, that is in the process of communication between the participants within political activity. The most important for political linguistics, the term discourse is not yet the only definition.

The formation of socio-political, legal, military terms is not accidental in nature, but is mostly regulated and modeled. Political dictionaries capture the most varied semantic changes, transformations that took place in oral and written language, including euphemism.

The question of political euphemism remains controversial. It would be advisable to pay more attention to this aspect and to investigate this phenomenon more thoroughly.

Key words: structural and functional aspects of language, role of interlocutor, euphemism, political euphemisms, dysphemism, discourse, manipulative aspect. 